\title{
Gastroschisis Treatment: Evaluation of Surgical Techniques and Results
}

\section{Gastroşizis Tedavisi; Cerrahi Teknikler ve Sonuçların Değerlendirilmesi}

(1) Emine İNCE, iD Semire Serin EZER, iD Abdülkerim TEMIZ, iD Hasan Özkan GEZER, ib Akgün HiÇSÖNMEZ

Başkent University Faculty of Medicine, Department of Pediatric Surgery, Adana, Turkey

\begin{abstract}
Objective: Recently, achieving good cosmetic results for patients with gastroschisis has gained popularity, as since the visceral organs can be safely positioned into the abdominal cavity. We aimed to evaluate patient outcomes while focusing on the cosmetic results to contribute to the limited amount of data on this subject in the literature.

Methods: From January 2005 to May 2018, patients operated on for gastroschisis in a single institution were evaluated retrospectively.

Results: Twenty-two patients with gastroschisis were treated (10 females/12 males). The mean gestational age was $38.2 \pm 2.1$ weeks. The mean birth weight was $2256.9 \pm 418.2 \mathrm{~g}$. Eleven patients were diagnosed prenatally. Five patients had complex gastroschisis. Others presented with necrosis $(n=3)$, perforation $(n=3)$, volvulus $(n=1)$ and jejunal atresia $(n=1)$. Primary closure $(n=16)$ and staged closure $(\mathrm{n}=6)$ were performed. Patients needed mechanical ventilation and total parenteral nutrition for $3.7 \pm 1.0$ days and $24.3 \pm 9.7$ days, respectively. Enteral feeding was started at $15.9 \pm 10.5$ days. The duration of hospitalisation was $36.7 \pm 13.3$ days. Three patients died from sepsis and multi-organ failure.

Conclusion: We believe that performing appropriate gastroschisis surgery at the same hospital without transferring to another centre is the main factor in achieving a successful outcome. Good cosmetic results and visceral function were achieved in this study in $86.3 \%$ patients.
\end{abstract}

Keywords: Abdominal wall defects, gastroschisis, neonatal surgery

\section{ÖZ}

Amaç: Son zamanlarda, gastroşizisli hastalar için iyi bir kozmetik sonuç elde etmek, visceral organları karın boşluğuna güvenle yerleştirmek kadar popülerlik kazanmaktadır. Çalışmanın amacı, kozmetik sonuçlara odaklanarak hastaların sonuçlarını değerlendirmek ve literatürde kozmetik sonuçlara odaklanan sınırlı sayıdaki verilere katkıda bulunmaktır.

Yöntemler: Ocak 2005'ten Mayıs 2018'e kadar gastroşizis nedeniyle opere edilen tüm hastaların tıbbi kayıtları geriye dönük olarak değerlendirildi.

Bulgular: Gastroşizisi olan 22 hasta tedavi edildi (10 kız/12 erkek). Ortalama gebelik yaşı $38,2 \pm 2,1$ hafta idi. Ortalama doğum ağırlığı $2256,9 \pm 418,2$ g idi. Onbir hastaya doğum öncesi tanı kondu. Beş hastada komplike gastroşizis vardı; nekroz $(n=3)$, perforasyon $(n=4)$, volvulus $(n=1)$ ve jejunal atrezi $(n=1)$. Primer kapama $(n=16)$ veya aşamalı kapama $(n=6)$ yapıldı. Mekanik ventilasyon süresi ve total parenteral beslenme sırasıly $3,7 \pm 1$ gün ve $24,3 \pm 9,7$ gündü. Enteral beslenmeye $15,9 \pm 10,5$ günde başlandı. Hastanede kalış süresi $36,7 \pm 13,3$ gündü. Üç hasta sepsis ve multiorgan yetmezliği nedeniyle öldü.

Sonuç: Hastaların doğduğu hastanede opere olmasının ve uygun cerrahi prosedür seçilmesinin başarı şansının ana faktörleri olduğunu düşünüyoruz. Bu çalışmada hastaların \%86,3’ünde iyi kozmetik sonuçlar ve visseral fonksiyonlar elde edildi.

Anahtar Sözcükler: Abdominal duvar defekti, gastroşizis, yenidoğan cerrahisi

Address for Correspondence: Emine iNCE, Başkent University Faculty of Medicine, Department of Pediatric Surgery, Adana, Turkey

E-mail: inceemine@yahoo.com ORCID ID: orcid.org/0000-0002-0751-2768

Cite this article as: Ince E, Ezer SE, Temiz A, Gezer HÖ, Hiçsönmez A. Gastroschisis Treatment: Evaluation of Surgical Techniques and Results. Bezmialem Science 2020;8(4):338-343. 


\section{Introduction}

Gastroschisis, a congenital abdominal wall defect, causes the abdominal organs to be exposed to the amniotic fluid. The stomach, the small and the large bowels, the liver, the spleen and the bladder may protrude through the defect (1). Gastroschisis occurs in 3:10,000 live births and has a very poor prognosis (2). Gastroschisis can be either a complex abnormality involving other gastrointestinal anomalies, such as intestinal atresia, perforation, necrosis, volvulus, or a simple abnormality without other anomalies $(1,2)$.

Placement of the visceral organs back into the abdominal cavity safely for good functional maintenance and to ensure an acceptable cosmetic appearance is the main treatment principles of gastroschisis. Simultaneously, associated anomalies or complications should be identified and managed promptly and provided the appropriate nutrition support $(3,4)$.

The aim of this study is to describe the characteristics and outcomes of cases of gastroschisis and evaluate the repair methods and cosmetic results.

\section{Method}

This study was conducted at our institution after the approval of the ethical committee (05-February-2019: KA19/42). The study was conducted in compliance with the principles of the ethics committee and the Declaration of Helsinki. Twenty-one neonates diagnosed with gastroschisis in our hospital between January 2005 and May 2018 and were evaluated retrospectively. The patient data were collected and recorded for each patient, including the preoperative preparation of the neonate, maternal age, prenatal diagnosis, gestational age and gender, birth weight, co-existing malformations, surgical technique used, mechanical ventilation, complications, time of parenteral nutrition, time to begin oral feeding, postoperative cosmetic results and length of hospitalisation.

Resuscitation by covering the bowel with warm saline-soaked sterile gauzes and by infusing fluids and prophylactic antibiotics, such as ampicillin, aminoglycosides and metronidazole, was performed for all neonates initially. A nasogastric tube was inserted into all patients and allowed to drain freely. If the new-born was born at our centre, we covered the herniated organs with moist, warm gauze and transferred the baby to the operating room directly that is adjacent to the delivery room. Neonates who were born in another centre were transferred to the operating room after clinical stabilisation.

In our study, the decision to repair gastroschisis by primary closure or staged closure depended on the surgeon's personal experience, without the criterion as reported in the literature. After evaluation of the baby and ascertaining whether the abdominal contents cannot be reduced or reduction is not safe, a staged closure was performed. While this decision was being made, we observed that it was physically impossible due to viscera-abdominal disproportion, or the risk for abdominal compartment syndrome. If a complete reduction was deemed safe, then a primary closure was performed.
All patients, who were intubated previously during the operation, were transferred to our neonatal intensive care unit postoperatively. A central catheter was placed on the postoperative first day, and all patients were given total parenteral nutrition (TPN) support until bowel function returned.

\section{Surgical Technique \\ Primary Skin Closure}

Under general anaesthesia, we washed the bowel gently with warm saline. The bowel was carefully inspected for complex gastroschisis, including intestinal atresia, volvulus and other gastrointestinal anomalies. Then, the assistant tents the abdomen by upward traction on the umbilical cord, which has been kept deliberately long. Reduction of the bowel was continued, loop by loop, until the entire bowel was reduced to the abdominal cavity. The fascia, at least $5 \mathrm{~mm}$ from the junction of skin and without any dissection, was sutured with non-absorbable pursestring and tied firmly. Subsequently, another absorbable suture was placed using single sutures with the skin and cord side-byside (Figure 1).

\section{Staged Procedure}

A silastic silo material was used for larger defects that could not be closed primarily. The umbilical ligament was ligated and removed. Then, the silastic silo was properly cut and prepared. The layers of the abdominal wall, including skin, subcutaneous tissue and fascia, were separated from each other. Then, the silastic silo mesh was sutured with non-absorbable suture material to the peritoneum and fascia of the defect by at least $5 \mathrm{~mm}$ intervals to prevent sutured edge tears. After 3 days when the bowel gas and

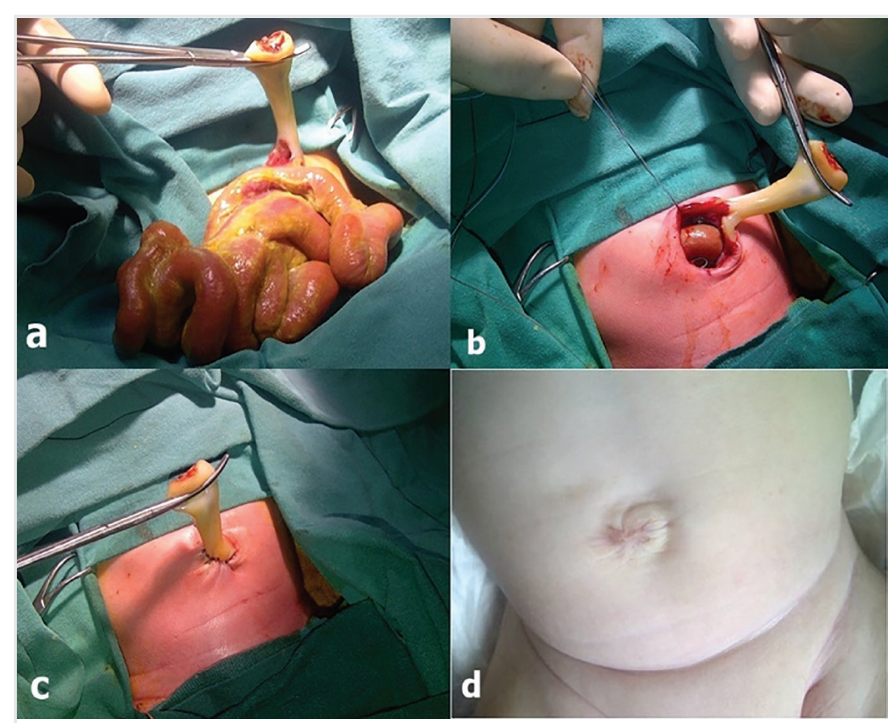

Figure 1. Primary closure for gastroschisis. (a) Reduction of the gut then until the entire bowel was within the abdominal cavity. (b) A non-absorbable purse-string suture was placed in the fascia. The purse-string suture in the fascia was tied firmly. (c) Another absorbable suture was placed using single sutures with the skin and cord side-byside. (d) At six weeks, full healing of the abdominal defect is shown and is a good cosmetic result for the patient. 
oedema lessens, the silastic silo was replaced, and a patch was employed (Dual Mesh ${ }^{\oplus}$, Gore-Tex ${ }^{\circ}$ ). Complete skin closure was successfully achieved after the patch was removed three weeks later (Figure 2).

Statistical analysis: This is a single-centre, retrospective, crosssectional and descriptive study. Patients were not randomly selected, and all patients had undergone surgery. Data were analysed using descriptive statistical tests based on data distribution.

\section{Results}

During the study interval, 22 patients with gastroschisis were admitted to our clinic (10 females and 12 males). Of these, seven patients were born at other hospitals. In our study, 11 patients were diagnosed as antenatal gastroschisis by ultrasonography, whereas the rest were without a prenatal diagnosis. The mean gestational age at the time of referral was $38.2 \pm 2.1$ weeks, and the mean birth weight was $2256.9 \pm 418.2 \mathrm{~g}$. Fourteen neonates were born via caesarean section; the other neonates were born via normal vaginal delivery (Table 1 ). The average age of mothers was $22.8 \pm 2$ years. All cases underwent abdominal ultrasonography and echocardiogram. Co-existing congenital anomalies including atrial septal defect $(n=5)$, patent ductus arteriosus $(n=2)$, meningocele $(n=1)$, cleft palate and micrognathia $(n=1)$ were detected. Seventeen neonates (77.2\%) had simple gastroschisis, whereas five infants $(22.7 \%)$ had complex gastroschisis; necrosis

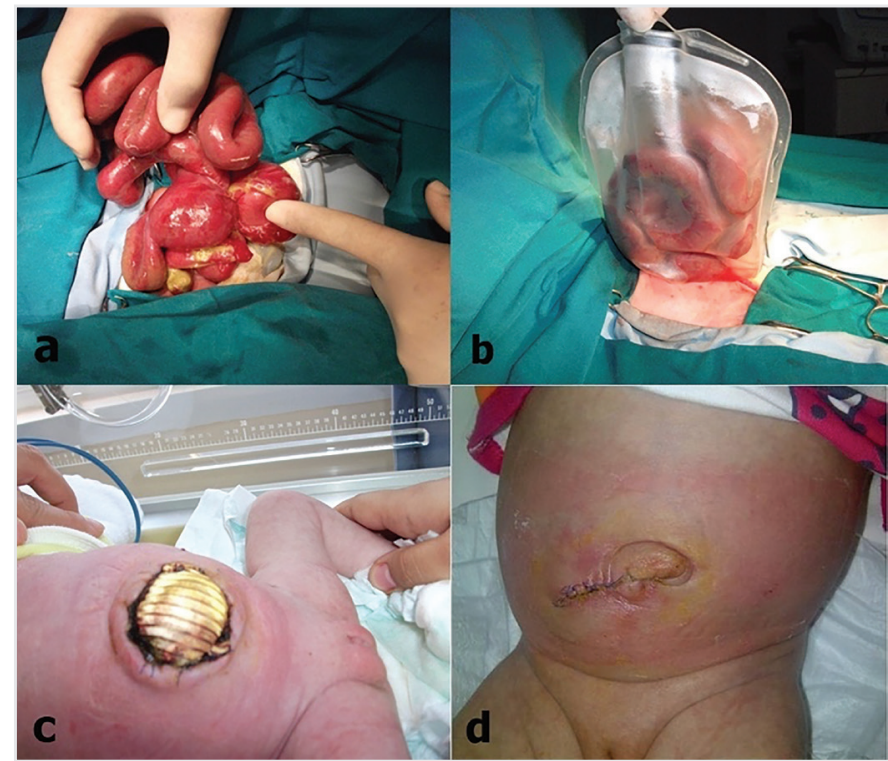

Figure 2. Staged closure for gastroschisis. (a) On day 1, the patient's exposed bowel is covered with a sterile silastic bag. When the bowel cannot be completely reduced (as shown here), the bag is tied off, forming a silo. (b) When the silastic silo had progressively lessened the bowel gas and oedema three days later, the bowel was reduced, and a patch was employed. (c) Complete skin closure was successfully achieved after the patch was removed three weeks later. (d) After two weeks, full healing of the abdominal defect is shown and is a good cosmetic result for the patient.

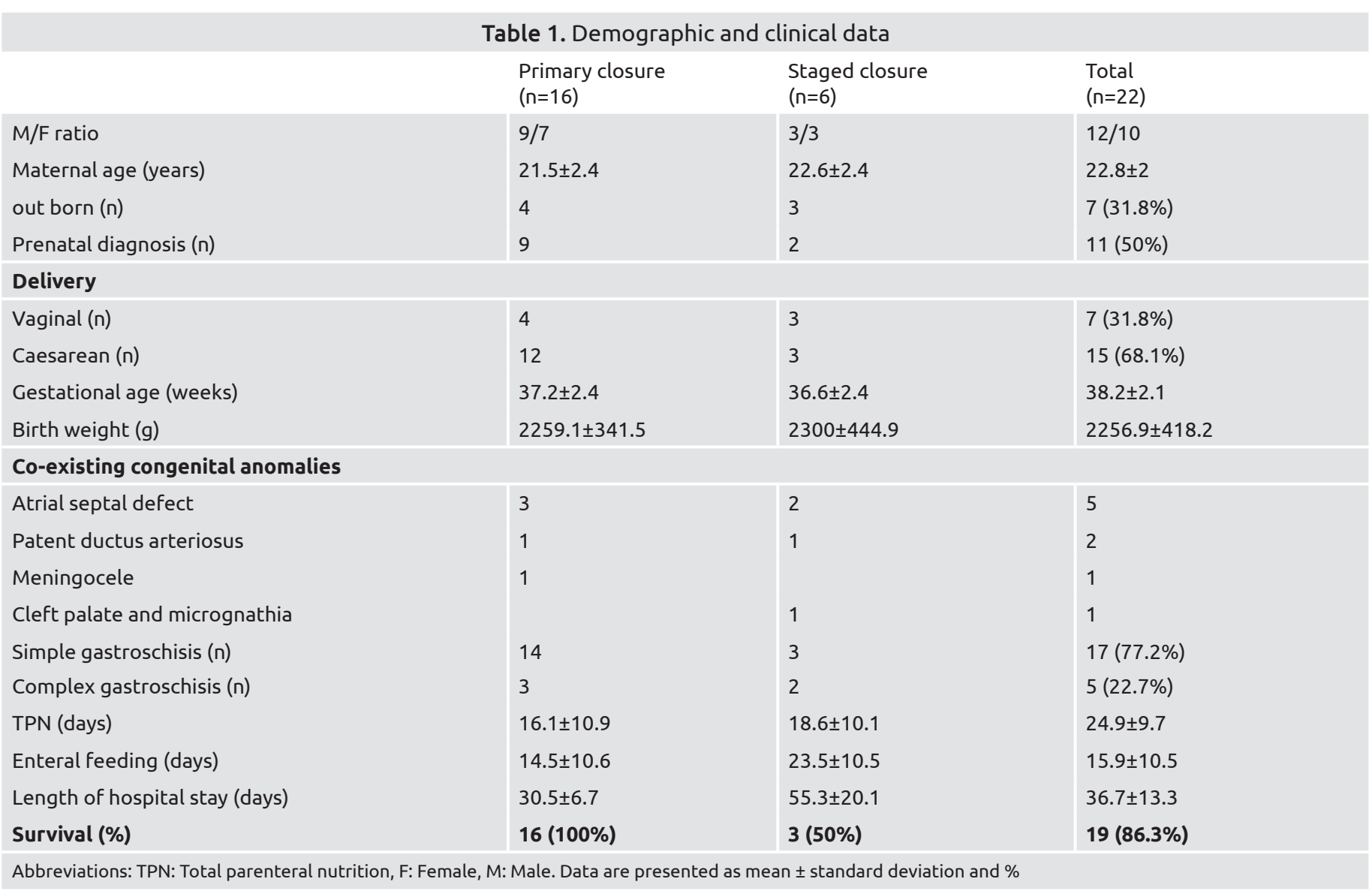


$(n=3)$, perforation $(n=4)$, mesenteric venous thrombosis and volvulus $(\mathrm{n}=1)$ and jejunal atresia $(\mathrm{n}=1)$ (Figure 3$)$.

Of the three cases of complex gastroschisis with bowel necrosis and perforation, one infant had jejunal atresia only, and the other infant had bowel necrosis and volvulus. Prematurity and low birth weight, weight less than $2000 \mathrm{~g}$ (range, 1,700-2,000 g), were more associated with neonates with complex gastroschisis. The diameters of the defects ranged from 2.5 to $6 \mathrm{~cm}$ (median, $3 \mathrm{~cm}$ ) in 22 of the gastroschisis cases. Sixteen patients were subjected to primary closure, and six underwent staged closure. None of the neonates in this study had abdominal compartment syndrome. The duration of mechanical ventilation and TPN were $3.7 \pm 1.0$ days and 24.3 \pm 9.7 days, respectively. Enteral feeding was started at $15.9 \pm 10.5$ days (Table 2 ).

One patient with complex gastroschisis (bowel necrosis and perforation) was subjected to primary closure and ileostomy. Three months later, this patient had contrast-enhanced tests and intestinal passage radiograms performed, which demonstrated the malrotation. This patient underwent the Ladd procedure and ostomy closure. Gastroschisis with jejunal atresia, rarely seen, was diagnosed 24 days later from primary closure of the abdominal wall. Of the six neonates who had undergone staged closure, two died in the early 48-hour postoperative period. The first

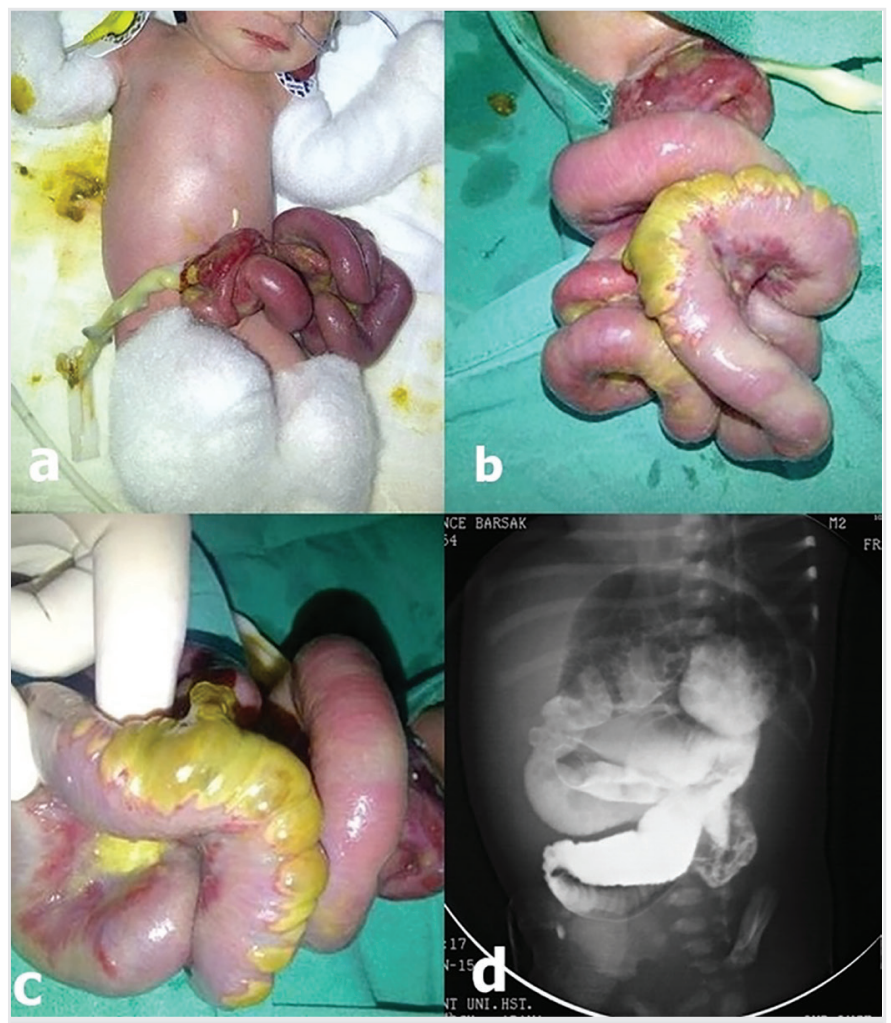

Figure 3. (a, b, c) One patient with complex gastroschisis (bowel necrosis and perforation) was subjected to primary closure and ileostomy. (d) Three months later, this patient had performed contrast-enhanced tests performed. Intestinal passage radiograms demonstrated the malrotation. The Ladd procedure and ostomy closure were performed on this patient. patient died of septicaemia, and the second patient died of bowel infarction caused by presumed mesenteric venous thrombosis and volvulus. Another patient who underwent primary closure died due to multi-organ failure from sepsis and ileus two months later. The duration of hospitalisation was $36.7 \pm 13.3$ days. All patients had an acceptable cosmetic appearance after the closure of the abdominal wall defect when they came for follow-up after discharge (Figures 1, 2).

\section{Discussion}

The treatment strategies of gastroschisis vary over a broad spectrum ranging from operative treatment, such as primary closure, staged closure, with or without general anaesthesia, to nonoperative treatment (3-8). Operative primary reduction, mostly depended on individual or selective cases, has become the standard initial surgical approach for more than 20 years. In contrast, operative staged reduction is typically associated with poorer cosmetic outcomes and is frequently used as a protective strategy when reduction is deemed unsafe or is physically impossible $(3,4,7,8)$. Recently, obtaining a good cosmetic result for patients with gastroschisis has gained popularity to put visceral organs safely into the abdominal cavity during the treatment. In our study, we obtain a good cosmetic result with putting visceral organs safely into the abdominal cavity in $86.3 \%$ of patients, most of whom had primary closure performed.

Gastroschisis, a rare congenital abdominal wall defect through which intra-abdominal organs herniate, requires surgical management soon after birth. Although antenatal diagnosis and care have improved during the last 30 years; some patients were not diagnosed during the antenatal period in our study (4). The mothers were not followed regularly during the prenatal period and usually give birth at regional maternity hospitals where paediatric surgeons do not work. On the other hand, infections during transfer caused sepsis in externally born infants (9). Therefore, if the conditions are suitable, neonates with antenatally diagnosed gastroschisis should be born in a paediatric surgical centre, since they will require surgery after delivery $(4,9)$. In our study, 11 patients were diagnosed as antenatal gastroschisis by ultrasonography, while the rest were without a prenatal diagnosis. Two of the transferred patients died early in the postoperative period. The first died of septicaemia and the second died from mesenteric venous thrombosis and intestinal infarction caused by volvulus. We believe that transferring patients from another centre increases the risk of mortality and morbidity due to improper physical conditions (insufficient fluid intake, hypovolemia and insufficient protection of the intestines). If the patient is diagnosed during the antenatal period, we recommend that the mother should be referred to a suitable centre for treatment of gastroschisis.

Young mothers have a high risk of having a child with gastroschisis $(10,11)$. In our study, the mean age of the mothers was $22.8 \pm 2$ years, and four of them were under 20 years of age.

The most common intestinal anomalies associated with gastroschisis are malrotation, midgut volvulus and atresia 
$(12,13)$. The diagnosis of intestinal atresia in gastroschisis can be difficult due to a thick inflammatory layer covering the intestines $(10,14,15)$. In our study, the diagnosis of jejunal atresia, which was not initially available to our patient, was made 24 days after closure of the abdominal wall. This patient had feeding intolerance for a long time and nasogastric tube drainage with marked abdominal distention. The contrast-enhanced test performed before the ostomy closure surgery revealed that the patient had intestinal malrotation.

Because of less parenteral nutrition and shorter hospital stay, primary closure of the gastroschisis is still considered an ideal correction (2-4). However, a tight closure during primary fascial repair may increase intra-abdominal pressure and the need for mechanical respiratory support. Therefore, it is necessary to consider the morbidity associated with mechanical ventilation $(4,14,16)$. In this procedure, the fascia was sutured with a nonabsorbable purse-string without any dissection and tied firmly. Thereafter, another absorbable suture was placed using single sutures with the skin and cord placed side-by-side. We consider that purse-string suture without dissection of the fascia has a role in the good cosmetic results. Abdominal compartment syndrome was not seen in any patients postoperatively. The mean duration of mechanical ventilation and TPN support was $3.7 \pm 1.0$ days and $24.3 \pm 9.7$ days, respectively. The mean time of starting enteral feeding was 35.9 \pm 4.6 days. In our series, there was no difference in the time to full enteral feeds and those reported in the literature.

On the other hand, when reduction is deemed unsafe or physically impossible, operative staged reduction is frequently used as a rescue strategy. Suturing a synthetic material to the enlarged defect in operative staged reduction was the safest approach, but was associated with worse cosmetic outcomes $(12,16)$. Sepsis, enteric fistula, prolonged ileus and the need for more surgeries is the causes of morbidity in silo use $(11,12,16)$. Another method is the suture-less method, which is applied to uncomplicated gastroschisis $(7,8)$. This method uses the umbilical cord as a biological dressing with non-adherent synthetic materials to reinforce it. In this method, a high incidence of umbilical hernia has been reported, but only a small percentage of patients require subsequent umbilical hernioplasty $(7,8)$.

We were presented with five patients who underwent staged closure. Silo and patch techniques are combined in our staged repair method. The main goal of the silastic silo management is to achieve sequential reduction. So, after a mean of 3 days, 1 when the bowel gas and oedema lessen, the bowel was reduced by replacing the silo with a patch. If the patch had been used in the first stage, the inspection of the vitality of the viscera and the sequential reduction of the intestines would not be possible. In addition, the sequentially reduced organs enable us to use a smaller sized patch. Three weeks later, the patch was removed, and complete skin closure was performed. Two patients with complex gastroschisis died within the first 48 postoperative hours due to sepsis and multi-organ failure. One of these patients had mesenteric thrombus and volvulus during the first admission, followed by intestinal necrosis. The second patient had sepsis because he was not transported under appropriate conditions.

None of our patients developed an umbilical hernia. Our 19 patients were reported to have good cosmetic appearance during outpatient follow-up.

The limitation of our study is that its relatively small sample size may not reflect global gastroschisis. The demographic data of our study patients are largely in line with those in the literature, and the therapeutic approach in our clinic complies with the international trend.

\section{Conclusion}

We believe that performing appropriate gastroschisis surgery at the same hospital without transferring to another centre is the main factor in achieving a successful outcome. Good visceral function and acceptable cosmetic results were achieved by our surgical techniques in $86 \%$ of our patients. Although many modifications have been tried in recent years to obtain good cosmetic results, we believe that good cosmetic results can be achieved with primary closure using the newest methods when experienced surgeons perform the procedure.

\section{Ethics}

Ethics Committee Approval: This study was conducted at our institution after the approval of the ethical committee (05-February-2019:KA19/42).

Informed Consent: The study was conducted in compliance with the principles of the ethics committee and the Declaration of Helsinki.

Peer-review: Internally peer reviewed.

\section{Authorship Contributions}

Concept: E.İ., S.S.E., A.T., H.Ö.G., A.H., Design: E.İ., S.S.E., A.T., H.Ö.G., A.H., Data Collection or Processing: E.İ., S.S.E., A.T., H.Ö.G., A.H., Analysis or Interpretation: E.İ., S.S.E., A.T., H.Ö.G., A.H., Literature Search: E.İ, S.S.E., A.T., H.Ö.G., A.H., Writing: E.İ., S.S.E., A.T., H.Ö.G., A.H.

Conflict of Interest: No conflict of interest was declared by the authors.

Financial Disclosure: The authors declared that this study received no financial support.

\section{References}

1. Abdullah F, Arnold MA, Nabaweesi R, Fischer AC, Colombani PM, Anderson KD, et al. Gastroschisis in the United States 19882003: analysis and risk categorization of 4344 patients. J Perinatol 2007;27:50-5.

2. Rahn S, Bahr M, Schalamon J, Saxena AK. Single-center 10-year experience in the management of anterior abdominal wall defects. Hernia 2008;12:345-50.

3. Owen A, Marven S, Johnson P, Kurinczuk J, Spark P, Draper ES, et al. Gastroschisis: a national cohort study to describe contemporary surgical strategies and outcomes. J Pediatr Surg 2010;45:1808-16. 
4. Schmidt AF, Gonçalves A, Bustorff-Silva JM, Oliveira Filho AG, Marba ST, Sbragia L. Does staged closure have a worse prognosis in gastroschisis? Clinics (Sao Paulo) 2011;66:563-6.

5. Bianchi A, Dickson AP. Elective delayed reduction and no anesthesia: 'minimal intervention management' for gastroschisis. J Pediatr Surg 1998;33:1338-40.

6. Kimble RM, Singh SJ, Bourke C, Cass DT. Gastroschisis reduction under analgesia in the neonatal unit. J Pediatr Surg 2001;36:1672-4.

7. Riboh J, Abrajano CT, Garber K, Hartman G, Butler MA, Albanese CT, et al. Outcomes of sutureless gastroschisis closure. J Pediatr surg 2009; 44:1947-51.

8. Choi WW, McBride CA, Bourke C, Borzi P, Choo K, Walker R, et al. Long-term review of sutureless ward reduction in neonates with gastroschisis in the neonatal unit. J Pediatr Surg 2012;47;1516-20.

9. Du L, Pan WH, Cai W, Wang J, Wu YM, Shi CR. Delivery room surgery: an applicable therapeutic strategy for gastroschisis in developing countries. World J Pediatr 2014;10:69-73.

10. Orion KC, Krein M, Liao J, Shaaban, AF, Pitcher GJ, Shilyansky J. Outcomes of plastic closure in gastroschisis. Surgery 2011;150:17785 .
11. Arnold M. Is the incidence of gastroschisis rising in South Africa in accordance with international trends? A retrospective analysis at Pretoria Academic and Kalafong Hospitals, 1981-2001. S Afr J Surg 2004;42:86-8.

12. Emil S, Canvasser N, Chen T, Friedrich E, Su W. Contemporary 2-year outcomes of complex gastroschisis. J Pediatr Surg 2012;47:1521-8.

13. Zvizdic Z. Gastroschisis with Concomitant Jejuno-Ileal Atresia Complicated by Jejunal Perforation. J Neonatal Surg 2016;10:5:25.

14. Bauman Z, Nanagas V Jr. The Combination of Gastroschisis, Jejunal Atresia, and Colonic Atresia, and Colonic Atresia in Newborn. Case Rep Pediatr 2015;2015:129098. [Epub 2015 Jun 9]

15. Snyder CL, Miller KA, Sharp RJ, Murphy JP, Andrews WA, Holcomb GW 3rd, et al. Management of intestinal atresia in patients with gastroschisis. J Pediatr Surg 2001;36:1542-5.

16. Ionescu S, Andrei B, Tirlea S, Bunea B, Licsandru E, Cirstoveanu $\mathrm{C}$, et al. Considerations on gastroschisis repair. Chirurgia (Bucur) 2013;108:509-15. 